\title{
SOCIETAL RISK PERCEPTION: A 19-COUNTRY COMPARISON
}

\author{
Bruno Chauvin \\ University of Nantes, France \\ Dimitra Macri \\ Polytechnic Institute, Piraeus University, Greece \\ Etienne Mullet ${ }^{1}$ \\ Ecole Pratique des Hautes Etudes, France
}

\begin{abstract}
Résumé
L'objectif de cette recherche a été de structurer les différences interculturelles observées dans la littérature à propos de la perception de risques, à l'aide d'analyses en clusters. A partir des estimations moyennes de risques disponibles dans la littérature, une matrice regroupant 30 risques et 19 pays a été constituée puis examinée selon une analyse en cluster. Six clusters de pays ont été observés : un cluster intitulé Bloc communiste (composé de l'URSS et de la Hongrie), un cluster Nordique (composé de la Finlande, de la Norvège, et de la Suède), un cluster Arabe (composé de l'Égypte et du Koweït), un cluster intitulé Pays en voie de développement (composé du Brésil et de la Corée du Sud), un cluster Occidental (composé de la France, du Portugal, de l'Espagne, et des États-Unis), et un cluster composé de quatre pays ou territoires (le Burkina Faso, la Chine via HongKong, la Chine via Macao, et la Russie) dont le seul dénominateur commun semble être l'existence de nombreux problèmes économiques et/ou sociaux. Les facteurs qui peuvent être à l'origine de ces regroupements en clusters sont discutés, et une nouvelle approche plus analytique pour rendre compte des différences interculturelles de perception des risques est suggérée.
\end{abstract}

Acest studiu a avut ca scop structurarea diferențelor trans-naționale în percepția riscurilor care au fost raportate în literatura de specialitate, utilizând analiza de clusteri. O matrice, care grupează 30 de riscuri şi 19 țări, a fost compusă utilizând ca input estimările medii ale riscurilor disponibile în literatură, iar analiza de clusteri a fost realizată pe această matrice. Au fost identificați şase clusteri de țări: clusterul Blocului Comunist (URSS şi Ungaria), clusterul Nordic (Finlanda, Norvegia şi Suedia), un cluster Arab (Egipt şi Kuweit), un cluster al Țărilor în dezvoltare (Brazilia şi Coreea de Sud), un cluster Vestic (Franța, Portugalia, Spania, USA) şi un cluster compus din patru țări sau teritorii (Burghina Faso, China - Hong - Kong, China - Macao, Rusia) al căror singur numitor comun este faptul că în toate există o serie de probleme economice şi/ sau sociale. Factorii ce pot explica această împărțire în clusteri sunt discutați şi este sugerată o abordare nouă, mai analitică, la nivelul diferențelor trans-naționale în ceea ce priveşte percepția riscurilor.

Mots-clés: perception des risques sociétaux, différences interculturelles dans la perception des risques, analyse en clusters, couverture médiatique.

\footnotetext{
1 Adresa de contact: Etienne Mullet, Quefes 17 bis, F-31830 Plaisance du Touch, France. E-mail: <etienne.mullet@wanadoo.fr>. This work was supported by the UPRES Education, Cognition and Development (Nantes University), the Laboratoire Ethique \& Travail (Ecole Pratique des Hautes Etudes), the SAFE European Network of Excellence, and the "Université de Toulouse" (UTM, CNRS, EPHE, CLLE-LTC). Thanks are extended to Sheila Rivière for his many helpful suggestions.
} 


\section{Introduction}

In our so-called modern societies, the management and communication of societal risks presuppose that experts, politicians, and ordinary citizens from the same country or from different countries share the same framework as regards risk assessment or are well aware of the differences in viewpoints that may oppose them. Conflicts and misunderstandings between experts, politicians and citizens may arise from differences in beliefs as regards determined facts and/or from differences in beliefs about what matter most and what does not matter much when assessing and/or managing societal risks (Slovic, 1987).

Studies on societal risk perception by Slovic, Fischhoff and Lichtenstein (1985) have been the impetus for numerous similar investigations in a variety of countries, in Africa (Ahmed, Macri \& Mullet, 2007, Koné \& Mullet,
1994), in Asia (e.g., Cha, 2000, Keown, 1989, Neto \& Mullet, 2001), in Europe (e.g., Bouyer, Bagdassarian, Chaabane \& Mullet, 2001, Chauvin, Hermand \& Mullet, 2007, Goszczynska, Tyszka \& Slovic, 1991), in Latin America (e.g., Nyland, 1993), and in Oceania (Finucane \& Maybery, 1996, Rohrmann, 1994). A list of these studies is shown in Table 1. In these studies, participants were instructed to rate the overall severity of hazards such as nuclear waste, homeopathic drugs, alcoholic beverage, smoking, and pesticides on scales ranging from 0 (not at all risky) to 100 (extremely risky). As most of these studies used questionnaires that were similar to the one used by Slovic Fischhoff and Lichtenstein (1985), and as most of these studies included samples of students, multiple cross-country comparisons have been made possible.

Table 1. Works devoted to the study of perceived risk magnitude, using Slovic, Fischhoff \& Lichtenstein questionnaire or parts of it $(\mathrm{N}=26)$.

\begin{tabular}{|c|c|c|c|c|c|}
\hline Authors & Year & Country & $\begin{array}{c}\text { Number of } \\
\text { items }\end{array}$ & $\begin{array}{c}\text { Sample } \\
\text { Size }\end{array}$ & Code \\
\hline Slovic, Fischhoff \& Lichtenstein & 1985 & USA & 90 items & 175 & USA \\
\hline Englander, Farago, Slovic \& Fischhoff & 1986 & Hungary & 86 items & 30 & $\mathrm{H}$ \\
\hline Teigen, Brun \& Slovic & 1988 & Norway & 90 items & 35 & $\mathrm{~N}$ \\
\hline Keown & 1989 & Hong Kong & 30 items & 65 & HK \\
\hline Mechitov \& Rebrik & 1990 & USSR & 56 items & 25 & SU \\
\hline Goszczynska, Tyszka \& Slovic & 1991 & Poland & 40 items & 140 & $P L$ \\
\hline Brun & 1992 & Norway & 75 items & 106 & \\
\hline Karpowicz-Lazreg \& Mullet & 1993 & France & 90 items & 107 & \\
\hline Nyland & 1993 & Brazil & 101 items & 144 & $\mathrm{BR}$ \\
\hline Nyland & 1993 & Sweden & 101 items & 119 & $\mathrm{~S}$ \\
\hline Koné \& Mullet & 1994 & Burkina Faso & 90 items & 51 & $\mathrm{BF}$ \\
\hline Rohrmann & 1994 & Australia & 24 items & 339 & \\
\hline Finucane \& Maybery & 1996 & Australia & 30 items & 40 & \\
\hline Savadori, Rumiati \& Bonini & 1998 & Italy & 38 items & 258 & \\
\hline Savadori, Rumiati, Bonini \& Pedon & 1998 & Italy & 38 items & 160 & \\
\hline Neto \& Mullet & 2000 & Portugal & 89 items & 99 & $P$ \\
\hline Cha & 2000 & Korea & 70 items & 60 & ROK \\
\hline Neto \& Mullet & 2001 & Macao & 87 items & 111 & PRC \\
\hline Bouyer, Bagdassarian, Chaabane \& Mullet & 2001 & France & 141 items & 363 & \\
\hline Macri \& Mullet & 2003 & Greece & 141 items & 407 & GR \\
\hline Mullet, Lazreg, Candela, \& Neto & 2005 & Finland & 90 items & 120 & FIN \\
\hline Munoz Sastre, Gatelier, Portell, Neto \& Mullet & 2006 & Spain & 94 items & 156 & $E$ \\
\hline Ahmed, Macri \& Mullet & 2006 & Egypt & 141 items & 430 & ET \\
\hline Chauvin, Hermand \& Mullet & 2007 & France & 141 items & 795 & $\mathrm{~F}$ \\
\hline Rodionova, Vinsonneau, Rivière \& Mullet & 2007 & Russia & 109 items & 800 & RUS \\
\hline Ahmed \& Mullet & 2007 & Kuwait & 141 items & 576 & KWT \\
\hline
\end{tabular}

Note: All these studies involved at least one sample of College students. 
These studies have shown that risk ratings may substantially vary from one country to another. For example, the level of risk associated with the item "Nuclear Power" was rated 31 (out of 100; that is, not very risky) in a Hungarian sample (Englander, Farago, Slovic \& Fischhoff, 1986), 34 in a Swedish sample (Nyland, 1993), 47 in a Norwegian sample (Teigen, Brun \& Slovic, 1988), an Australian sample (Finucane \& Maybery, 1996), and a Finnish sample (Mullet, Lazreg, Candela \& Neto, 2005), 49 in a Polish sample (Goszcynska, Tyszka \& Slovic, 1991), 62 in an Italian sample (Savadori, Rumiati \& Bonini, 1998), 66 in a Macanese sample (Neto \& Mullet, 2001) and a Brazilian sample (Nyland, 1993), 67 in a Portuguese sample (Neto \& Mullet, 2000), 68 in a Hong Kongese sample (Keown, 1989), 69 in a French sample (Karpowicz-Lazreg \& Mullet, 1993) and a Russian sample (Rodionova, Vinsonneau, Rivière \& Mullet, 2007), 72 in a US sample (Slovic, Fischhoff \& Lichtenstein, 1985) and a Korean sample (Cha, 2000), 78 in a Burkina Faso sample (Koné \& Mullet, 1994), 79 in an Egyptian sample (Ahmed, Macri \& Mullet, 2006) and a Kuwaiti sample (Ahmed \& Mullet, 2007), 84 in a Spanish sample (Muñoz Sastre, Gatelier, Portell, Neto \& Mullet, 2006), and 89 in a Greek sample (Macri \& Mullet, 2007).

These studies have also shown that mean risk ratings; that is, overall level of concern with societal risk, may vary considerably from one country to another. Overall mean ratings, computed over about 50 common items, range from about 17 (Mechitov \& Rebrik, 1990) to about 52 (Macri \& Mullet, 2007) out of 100 .

These studies have finally shown that associations (linear correlations) between these ratings; that is, similarity-dissimilarity of rankings between countries, were equally variable. Overall correlation coefficients computed over common subsets of items (the ones common to both countries each time) ranged from about .05 (between Soviet Union and Macao) to about .95 (between Kuwait and Egypt).

\section{Structuring the Differences}

\subsection{Constituting a Similarity Matrix}

The present study was aimed at structuring the differences in risk perception that have been reported in the literature, using cluster analysis. We created a data basis that contained all available risk ratings reported to date. The total number of hazards that have been examined in the 26 studies listed in Table 1 was 264 . As a result, a 264 x 26 data matrix was created. All the hazards were, however, not included in all the studies. As a result, this matrix contained many blank cells. In order to minimize the number of blank cells, this matrix was subsequently reduced to a $30 \times 19$ matrix; that is, 30 hazards were selected (the ones that compose the questionnaire used in Hong Kong by Keown, 1989, see Table 2), and 19 countries for which ratings on these 30 hazards were available were selected (the ones for which a code has been indicated in Table 1). Columns 2 and 3 in Table 2 show the mean ratings and standard deviations computed over these 19 countries for each selected hazard.

\subsection{A Six-Cluster Solution}

A cluster analysis was conducted on the matrix. The results are shown in Figure 1. Six clusters of countries were found. The first cluster comprised two countries (USSR and Hungary) that formed part of the Communist block. Data from these countries were gathered before the fall of the wall. They are fossil data. The mean rating value observed on the set of 30 common hazards was about 23 (see Table 3). This low value is consistent with the fact that in the former Communist block countries, the media rarely reported accidents and misfortunes because information on risks was strictly censored (Goszczynska et al., 1991; Sjöberg, Kolarova, Rucai, Bernström, \& Flygelholm, 1996). The news media gave very little coverage to hazards taking place inside the country, and mainly reported accidental deaths occurring outside the country, leading the people to believe that accidents only happened elsewhere. In other words, Hungarian and Soviet news, in Kasperson et al.'s (1988) terminology, "attenuated" risks (Boholm, 1998; Englander et al., 1986).

The second cluster comprised three countries (Finland, Norway, Sweden) that are geographically and culturally close. The mean rating value observed on the set of 30 common hazards was about 33 (see Table 3). Although this value is higher than the one observed in the first cluster, it is, however, still relatively low. 
Table 2. Mean Ratings (and Standard Deviations) of Perceived Risk for the 30 Selected Hazards Computed over 19 Selected Countries and Over Clusters.

\begin{tabular}{|c|c|c|c|c|c|c|c|c|}
\hline \multirow[b]{2}{*}{ Items } & \multicolumn{2}{|c|}{ Overall } & \multirow{2}{*}{$\begin{array}{c}\mathrm{CB} \\
\mathrm{M}\end{array}$} & \multirow{2}{*}{$\begin{array}{c}\mathrm{NC} \\
M\end{array}$} & \multirow{2}{*}{$\begin{array}{c}\mathrm{AC} \\
\mathrm{M}\end{array}$} & \multirow{2}{*}{$\begin{array}{c}\mathrm{DC} \\
M\end{array}$} & \multirow{2}{*}{$\begin{array}{c}\mathrm{WC} \\
M\end{array}$} & \multirow{2}{*}{$\begin{array}{c}\mathrm{OC} \\
M\end{array}$} \\
\hline & $M$ & $S D$ & & & & & & \\
\hline Nuclear weapons & 81.16 & 15.59 & & 64.82 & 93.08 & 94.19 & 84.71 & 82.75 \\
\hline Heroin & 75.22 & 20.01 & 25.05 & 72.15 & 89.23 & 89.30 & 80.68 & 81.39 \\
\hline Warfare & 74.49 & 19.28 & 35.95 & 57.08 & 84.98 & 92.29 & 79.12 & 82.16 \\
\hline Crime & 72.26 & 20.14 & 35.80 & 49.08 & 87.43 & 84.57 & 82.05 & 81.76 \\
\hline Handguns & 67.68 & 21.77 & 23.40 & 44.72 & 77.58 & 83.20 & 80.86 & 76.64 \\
\hline Nuclear power & 65.02 & 16.04 & & 42.77 & 79.13 & 69.37 & 73.43 & 70.23 \\
\hline Smoking & 64.55 & 10.24 & 50.35 & 55.92 & 79.98 & 65.24 & 71.46 & 64.72 \\
\hline Alcoholic beverages & 54.93 & 13.76 & 52.45 & 36.45 & 83.38 & & 57.29 & 48.74 \\
\hline DDT & 53.96 & 12.37 & & 47.43 & 52.90 & & 68.96 & \\
\hline Pesticides & 51.26 & 13.69 & 32.70 & 36.08 & 55.05 & 64.07 & 64.89 & 51.39 \\
\hline Radiation therapy & 46.59 & 13.72 & 20.10 & 34.70 & 59.64 & 56.75 & 50.71 & 48.82 \\
\hline Motor vehicles & 46.06 & 11.49 & 31.35 & 37.44 & 38.54 & & 51.92 & 51.11 \\
\hline Chemical fertilizers & 43.68 & 15.68 & 32.85 & 28.26 & 44.42 & 51.52 & 54.95 & 37.95 \\
\hline Fireworks & 40.89 & 19.07 & 10.00 & 27.44 & 68.52 & 61.49 & 40.85 & 37.91 \\
\hline Diagnostic X-rays & 40.19 & 16.64 & 16.05 & 16.39 & 59.44 & 43.30 & 46.74 & 45.95 \\
\hline Food coloring & 38.82 & 13.25 & & & 60.40 & & 36.12 & 42.70 \\
\hline Food preservatives & 37.78 & 13.43 & & 22.35 & 40.76 & 52.64 & 39.37 & 41.32 \\
\hline DNA research & 36.52 & 13.77 & 15.75 & 24.01 & 52.45 & 32.32 & 50.92 & 32.10 \\
\hline Oral contraceptives & 36.02 & 11.93 & 17.10 & 23.61 & 47.61 & 39.20 & 36.34 & 44.68 \\
\hline $\begin{array}{l}\text { Non nuclear electric } \\
\text { power }\end{array}$ & 34.81 & 7.99 & 31.25 & 24.16 & & 44.89 & & 39.09 \\
\hline Railroads & 34.55 & 14.39 & 19.85 & 24.36 & 32.99 & 69.39 & 30.72 & 37.36 \\
\hline Space exploration & 33.78 & 12.97 & 16.70 & 18.37 & 35.34 & & 36.09 & 41.13 \\
\hline Caffeine & 33.14 & 12.29 & 20.65 & 16.39 & 41.96 & 45.94 & 32.44 & 41.39 \\
\hline Commercial aviation & 30.79 & 9.59 & 17.90 & 19.41 & & 37.42 & & 42.82 \\
\hline Sunbathing & 28.72 & 13.80 & 10.30 & 23.34 & 30.64 & & 39.35 & 27.40 \\
\hline Microwave owens & 28.36 & 11.81 & 9.25 & 12.43 & 37.24 & 31.57 & 32.35 & 38.00 \\
\hline Pregnancy/childbirth & 27.62 & 8.65 & 16.40 & 16.94 & 26.91 & & 28.90 & 35.38 \\
\hline Recreational boating & 26.78 & 8.15 & 16.05 & 19.53 & 36.59 & & 26.32 & 31.67 \\
\hline Bicycles & 24.70 & 10.77 & 14.65 & 19.63 & 30.20 & 23.32 & 21.46 & 27.31 \\
\hline Cosmetics & 23.48 & 11.03 & 5.75 & & 43.94 & & 20.26 & 28.51 \\
\hline
\end{tabular}

Table 3. Means and Standard Deviations Computed over the Common Items.

\begin{tabular}{|c|c|c|c|c|c|}
\hline Country & $M$ & $S D$ & Clusters & $M$ & $S D$ \\
\hline USSR & 19.83 & 13.50 & \multirow{2}{*}{ Communist block } & \multirow{2}{*}{23.11} & \multirow{2}{*}{12.05} \\
\hline Hungary & 25.78 & 15.36 & & & \\
\hline Finland & 32.78 & 13.46 & \multirow{3}{*}{ Nordic countries } & \multirow{3}{*}{32.69} & \multirow{3}{*}{16.06} \\
\hline Sweden & 32.62 & 19.55 & & & \\
\hline Norway & 30.72 & 17.91 & & & \\
\hline Kuwait & 54.69 & 20.46 & \multirow{2}{*}{ Arab countries } & \multirow{2}{*}{56.08} & \multirow{2}{*}{20.89} \\
\hline Egypt & 57.47 & 21.88 & & & \\
\hline Greece & 60.59 & 19.28 & & & \\
\hline South Korea & 61.48 & 21.79 & \multirow{2}{*}{ Developing countries } & \multirow{2}{*}{58.66} & \multirow{2}{*}{21.33} \\
\hline Brazil & 53.44 & 20.91 & & & \\
\hline France & 50.47 & 23.15 & \multirow{4}{*}{ Western countries } & \multirow{4}{*}{50.69} & \multirow{4}{*}{20.39} \\
\hline Spain & 52.81 & 23.93 & & & \\
\hline Portugal & 48.80 & 17.78 & & & \\
\hline USA & 46.76 & 20.21 & & & \\
\hline Poland & 45.47 & 21.99 & & & \\
\hline Russia & 49.82 & 19.15 & \multirow{4}{*}{ Other countries } & \multirow{4}{*}{48.70} & \multirow{4}{*}{17.77} \\
\hline Hong Kong & 49.73 & 17.85 & & & \\
\hline Macao & 50.61 & 18.50 & & & \\
\hline Burkina Faso & 44.69 & 19.06 & & & \\
\hline
\end{tabular}


This low value is consistent with what is known about the media policy information in these countries. Nyland (1993, pp. 46-47) mentioned that: "Swedish television seems to emphasize problems, wars, violence, deaths, and social convulsions taking place in different parts of the world outside Sweden. As a matter of fact, Swedish people do not suffer due to social convulsions and armed confrontations, but it should be fair to say that accidents and violence happen also in Sweden, and that this aspect is usually not present in the news... Swedish television does not usually focus on events taking place in their own police stations and emergency rooms. Since they do focus on other people's miseries and misfortunes, the impression left may be that bad things only happen outside Swedish borders". This second cluster must not be confused with the first one because, although overall means are close, rankings are different. Between the two sets of ratings the linear correlation is only .60, which in this context is considered as low (see Tables 4 and 5). In other words, the Norwegians, the Swedish, and the Finnish on the one hand and the Hungarians and the people in USSR on the other hand did not completely share the same main concerns (e.g., the Norwegian, Swedish and Finnish ratings on hazards such as heroin, handguns, or DNA research were clearly higher than the Hungarian and Soviet ratings).

Table 4. Linear Correlations Between the Common Items Computed at the Country Level.

\begin{tabular}{cccccccccccccccccccc}
\hline & $\mathrm{SU}$ & $\mathrm{H}$ & $\mathrm{FIN}$ & $\mathrm{S}$ & $\mathrm{N}$ & $\mathrm{KWT}$ & $\mathrm{ET}$ & $\mathrm{GR}$ & $\mathrm{ROK}$ & $\mathrm{BR}$ & $\mathrm{F}$ & $\mathrm{E}$ & $\mathrm{P}$ & $\mathrm{USA}$ & $\mathrm{PL}$ & $\mathrm{RUS}$ & $\mathrm{HK}$ & $\mathrm{PRC}$ & $\mathrm{BF}$ \\
\hline $\mathrm{SU}$ & 1 & .35 & .61 & .33 & .32 & .49 & .44 & .40 & .28 & .34 & .49 & .42 & .44 & .52 & .48 & .45 & .34 & .04 & .24 \\
$\mathrm{H}$ & .35 & 1 & .57 & .57 & .58 & .57 & .51 & .44 & .49 & .61 & .60 & .53 & .52 & .59 & .61 & .54 & .63 & .57 & .63 \\
$\mathrm{FIN}$ & .61 & .57 & 1 & .77 & .82 & .78 & .72 & .82 & .69 & .70 & .83 & .82 & .87 & .78 & .70 & .76 & .75 & .61 & .64 \\
$\mathrm{~S}$ & .33 & .57 & .77 & 1 & .91 & .77 & .70 & .77 & .80 & .84 & .83 & .81 & .78 & .77 & .87 & .87 & .83 & .78 & .76 \\
$\mathrm{~N}$ & .32 & .58 & .82 & .91 & 1 & .86 & .79 & .80 & .76 & .83 & .84 & .89 & .86 & .82 & .87 & .86 & .84 & .87 & .82 \\
$\mathrm{KWT}$ & .49 & .57 & .78 & .77 & .86 & 1 & .95 & .83 & .74 & .80 & .85 & .89 & .85 & .82 & .90 & .89 & .80 & .81 & .86 \\
$\mathrm{ET}$ & .44 & .51 & .72 & .70 & .79 & .95 & 1 & .74 & .76 & .78 & .74 & .78 & .79 & .69 & .89 & .80 & .73 & .74 & .79 \\
$\mathrm{GR}$ & .40 & .44 & .82 & .77 & .80 & .83 & .74 & 1 & .69 & .70 & .90 & .90 & .80 & .79 & .76 & .86 & .82 & .72 & .73 \\
$\mathrm{ROK}$ & .28 & .49 & .69 & .80 & .76 & .74 & .76 & .69 & 1 & .90 & .80 & .80 & .83 & .73 & .88 & .82 & .82 & .77 & .76 \\
$\mathrm{BR}$ & .34 & .61 & .70 & .84 & .83 & .80 & .78 & .70 & .90 & 1 & .74 & .79 & .76 & .74 & .92 & .84 & .85 & .86 & .84 \\
$\mathrm{~F}$ & .49 & .60 & .83 & .83 & .84 & .85 & .74 & .90 & .80 & .74 & 1 & .96 & .86 & .84 & .87 & .88 & .83 & .75 & .81 \\
$\mathrm{E}$ & .42 & .53 & .82 & .81 & .89 & .89 & .78 & .90 & .80 & .79 & .96 & 1 & .88 & .88 & .89 & .89 & .84 & .81 & .85 \\
$\mathrm{P}$ & .44 & .52 & .87 & .78 & .86 & .85 & .79 & .80 & .83 & .76 & .86 & .88 & 1 & .87 & .78 & .84 & .85 & .75 & .72 \\
$\mathrm{USA}$ & .52 & .59 & .78 & .77 & .82 & .82 & .69 & .79 & .73 & .74 & .84 & .88 & .87 & 1 & .87 & .88 & .87 & .76 & .73 \\
$\mathrm{PL}$ & .48 & .61 & .70 & .87 & .87 & .90 & .89 & .76 & .88 & .92 & .87 & .89 & .78 & .87 & 1 & .94 & .88 & .81 & .89 \\
$\mathrm{RUS}$ & .45 & .54 & .76 & .87 & .86 & .89 & .80 & .86 & .82 & .84 & .88 & .89 & .84 & .88 & .94 & 1 & .93 & .82 & .84 \\
$\mathrm{HK}$ & .34 & .63 & .75 & .83 & .84 & .80 & .73 & .82 & .82 & .85 & .83 & .84 & .85 & .87 & .88 & .93 & 1 & .85 & .82 \\
$\mathrm{PRC}$ & .04 & .57 & .61 & .78 & .87 & .81 & .74 & .72 & .77 & .86 & .75 & .81 & .75 & .76 & .81 & .82 & .85 & 1 & .84 \\
$\mathrm{BF}$ & .24 & .63 & .64 & .76 & .82 & .86 & .79 & .73 & .76 & .84 & .81 & .85 & .72 & .73 & .89 & .84 & .82 & .84 & 1 \\
\hline
\end{tabular}

Table 5. Linear Correlations Between the Common Items Computed at the Cluster Level.

\begin{tabular}{|c|c|c|c|c|c|c|c|c|}
\hline Clusters & CB & $\mathrm{NC}$ & $\mathrm{AC}$ & GR & $\mathrm{DC}$ & WC & $\mathrm{PL}$ & $\mathrm{OC}$ \\
\hline Communist block (CB) & 1 & .62 & .61 & .49 & .54 & .68 & .68 & .57 \\
\hline Nordic countries (NC) & .62 & 1 & .83 & .83 & .87 & .90 & .88 & .89 \\
\hline Arab countries (AC) & .61 & .83 & 1 & .79 & .82 & .85 & .90 & .86 \\
\hline Greece & .49 & .83 & .79 & 1 & .74 & .90 & .76 & .83 \\
\hline Developing countries (DC) & .54 & .87 & .82 & .74 & 1 & .84 & .90 & .89 \\
\hline Western countries (WC) & .68 & .90 & .85 & .90 & .84 & 1 & .88 & .92 \\
\hline Poland & .68 & .88 & .90 & .76 & .90 & .88 & 1 & .92 \\
\hline Other countries (OC) & .57 & .89 & .86 & .83 & .89 & .92 & .92 & 1 \\
\hline
\end{tabular}


The third cluster comprised two countries (Egypt and Kuwait) that are linguistically close. The mean rating value observed on the set of 30 common hazards was about 56 (see Table 3), which is considerably higher than what was observed in the first two clusters, hence the big gap between Cluster 3 and Cluster 2 that is shown in Figure 1. According to Ahmed, Macri and Mullet (2006) and Ahmed and Mullet (2007), differences in risk perception observed between the two countries forming this Arab group and the European countries (Cluster 1 and Cluster 2) may be explained by the existence of Arab press agencies (e.g., Kuwait News Agency: KUNA, Maghreb Arab Press), and Arab TV channels (e.g., Al Arabia, Al Jazirah) that are independent of the other press agencies. These media, which are usually controlled by the governments of the countries in which they operate, tend to report news in a way that is somewhat different from the way news are reported in other countries, notably in countries forming the Nordic cluster. Hence, Egyptian and Kuwaiti publics have access to specific information sources that emphasize aspects of hazards that are partly different from the ones European media use to emphasize. These possible main differences between the media information policies should be found in the domain of health hazards, environmental hazards, and common individual hazards. The linear correlation between ratings in this cluster and rating in the Nordic cluster is, however, about .80 (see Tables 4 and 5); that is, the Nordic group and the Arab group seems to share somewhat similar main concerns, though not to the same extent.

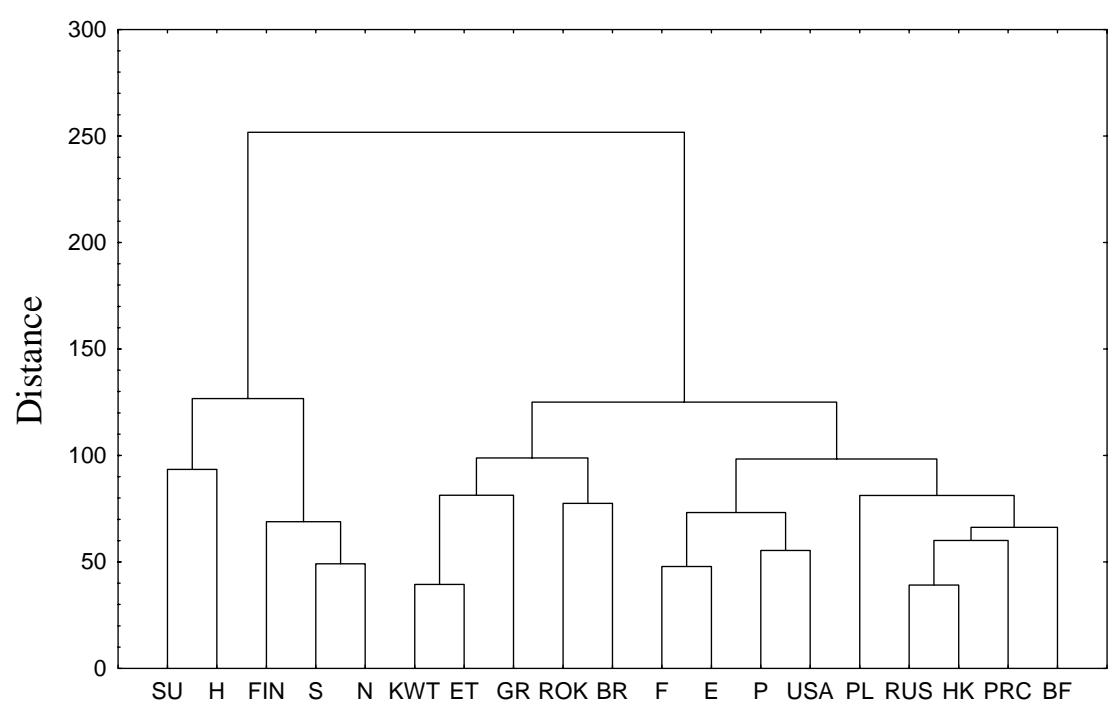

Figure 1. Results of the Cluster Analysis performed on the raw data from 19 Countries

The fourth cluster comprised two countries (Brazil and Korea) that are geographically and culturally far apart. Their common denominator is, however, that both are potent developing countries. The mean rating value observed on the set of 30 common hazards was about 59 (see Table 3); that is, still higher than the one that was observed in the Arab cluster. This is consistent with what is known about the side effects of development. Cha (2000, p. 49) noted that: "Most risks are generally related with the risks which have been caused by rapid Korean economic development. While the Korean government has propelled rapid economic development through projects such as building nuclear power plants, dams, skyscrapers, and roads, there has been relatively little emphasis on safety and risk management of the development process. As a result of the lack of considerations on safety and risk management, several severe disasters have occurred recently, including the collapse of several buildings and dams. These recent events may influence Korean risk perceptions". Nyland's (1993, p. 9) view about the situation in Brazil is similar: "Brazil has been intensively industrialized in the last twenty years, and regulation and control have not been developed side by side with the development of the country's industries". This is also consistent with what is known about the media information policy in this country: "The Brazilian television focuses mainly on 
accidents happening inside the country, and the Brazilian's own violence and misfortunes. This coverage is overwhelming. The Brazilian television emphasizes risk issues at least as much as any other television news program" (p. 48). The linear correlation between ratings in this cluster and rating in the Nordic cluster was, however, about .87 (see Tables 4 and 5). In other words, this cluster and the Nordic one essentially differ in the overall level of perceived risk, and practically not in the ranking of the hazards.

The fifth cluster comprised four countries (France, Portugal, Spain, USA) that are culturally close. All four countries form part of what is called the Western world. The mean rating value observed on the set of 30 common hazards was about 51 (see Table 3); that is, lower that what was observed in the Developing Countries cluster but clearly higher than the one that was observed in the first two clusters. In these four western countries, accidents both occurring inside and outside the borders of the country have always been systematically reported. The linear correlation between ratings in this cluster and rating in the Nordic cluster was surprisingly high: about .90 (see Tables 4 and 5). The Western cluster and the Nordic cluster only differ in the overall perceived risk level, not in the ranking of the hazards.

Finally, the sixth cluster comprised four countries or territories (Burkina Faso, ChinaHong-Kong, China-Macao, Russia) that are geographically and culturally apart. Their common denominator seems to be that these countries are countries in which many economical and/or societal problems exist, although these problems are of very different types. The mean rating value observed on the set of 30 common hazards was about 49 (see Table 3); that is, close to the one observed in the Western cluster. Also, the linear correlation between ratings in this cluster and ratings in the Western cluster was high: about .92 (see Tables 4 and 5). As a result, the fifth and sixth clusters may be considered as very close; namely, they tended to express the same main concerns practically to the same extent (e.g., there was no differences for hazards such as heroin, crime, or motor vehicles between the fifth and sixth clusters ratings).

This finding is consistent with what is known about the media information policy in these countries. The persons living in Burkina Faso (Koné \& Mullet, 1994), in Macao (Neto \& Mullet, 2001), and a large majority of Russians (Rodionova et al., 2007) have unrestricted access to international news provided by newspapers, radio, and TV programmes. In fact, the eight countries forming part of the Western cluster or of the sixth cluster share the same information pool. As a result, these populations appear sensitized to many similar health and environmental concerns. The countries forming part of the sixth cluster, however, by comparison with the countries in the Western cluster, face or have faced adverse economic, politic and/or social conditions. Burkina Faso is a country in Western Africa which is one of the poorest countries in the world. Violence is chronic in the form of attacks on the street or in the home; delinquency is widespread as a result of increasingly difficult living conditions (Koné \& Mullet, 1994). Macao seems to be in a particular political and economical situation, mainly dominated by gambling. In present day Russian society, unemployment, poverty and violence are common ingredients of everyday life (Rodionova et al., 2007). These adverse economic, societal or political conditions may explain why these countries showed a partly specific profile of risk perception.

The position of Poland in Figure 1 is interesting to consider. Poland is mid-way between the Western cluster and the sixth cluster. The Polish data were collected before the fall of the wall. They, however, show that, even at that time, and as regards information, Poland occupied a special position in the Communist world. According to Goszczynska, Tyszka, and Slovic (1991), reports of accidents were more common in Poland than in the other communist countries because there was an independent Catholic free press and numerous underground newspapers. Thanks to these information sources, the awareness of various risky hazards has increased considerably in Polish society, compared with others communist societies. This may explain why Poland appears much closer from the Western cluster than from the Communist countries cluster. In fact, the mean rating value observed on the set of 30 common hazards was about 45 , and the linear correlation between Poland and the Western cluster was .88.

The position of Greece in Figure 1 is also interesting to consider. Greece is mid-way between the Arab cluster and the Western cluster. What Greek participants and the members of the Arab cluster have in common is that they have judged several hazards as more risky than the participants in the Western cluster did, and these hazards were mainly common individual hazards, and health 
hazards (e.g., sexual or addictive activities). Despite these differences between Greek and Western ratings, the linear correlation with the Western cluster was, however, very high: about .90 .

\section{Complementary Findings on Cross- national Differences}

Indisputably, as demonstrated in the preceding section, means and linear associations are useful indices: They can be easily obtained, even with a reduced set of participants. Other indices are, however, greatly needed when one is interested in knowing more about cross-national differences and in tracing their origins (Sjöberg, 2000), and future studies on cross-national differences might be well advised to adopt more analytic approaches.

One way to better understand crossnational differences is to contrast two highly different countries regarding one well defined type of societal risk (e.g., violence), keeping other important influences as constant as possible. This was the strategy followed by Neto and Mullet (2001) who compared risk perception in Macao, China and Portugal. At the time of the study, Macao was a Chinese territory placed under Portuguese administration; that is, as briefly indicated above, Macao had a particular political and economic situation. In Macao, gambling dominated the economic activities, and a very large number of other businesses flourished around the casino-linked activities: loan sharking, pawn shops, clientele solicitation, prostitution, drug traffic, money laundering and private incarceration (after kidnapping). These businesses were run by various triad groups who frequently turned to violent crimes in case of disagreements. The news on criminal activities always had a wide coverage. In fact, as mentioned above, on various occasions, the public had criticized reporters for displaying shocking photographs, which can upset the more sensitive readers. Neto and Mullet's hypothesis was that this social (and media) reality should probably be reflected in people's perception of societal risks. In fact, they found that despite high similarity in mean results, standard deviations, and linear correlation with other countries, Macao appeared as the country in which the level of risk perception was clearly the highest (and this seemed largely due to five items connected with violence and crime).
Another way to better understand cross-national differences in societal risk perception is to rely on more fine-grained means comparisons. This is the strategy that was used in Macri and Mullet's (2007) study, which was based on a typology of hazards previously suggested by Bouyer et al. (2001). By factor analyzing a large Hazards $x$ Participants matrix of individual severity of risk ratings, Bouyer et al. (2001) were able to identify a parsimonious factor structure. Ten factors were evidenced: Common individual hazards (e.g., hair dyeing, computer screens), Pollutants (e.g., chemical plants, herbicides), Energy production and public transportation (e.g., hydroelectric power plant, railroads), Outdoor activities (e.g., swimming pools, power mowers), Sex, deviance and addictions (e.g., marijuana, heterosexual relationships with many partners), Domestic hazards (e.g., home appliances, air conditioning), Urban violence (e.g., violence at school), Medical care (e.g., open-heart surgery, clinics), Weapons (e.g., nuclear weapons, handguns), and Psychotropic drugs (e.g., sleeping pills, valium).

This finding demonstrated that judging risk severity possessed its own structure. In other words, there are categories of hazards that are collectively judged riskier by certain persons than by other persons, and these categories are sufficiently independent from one another to constitute separate factors. Using Confirmatory Factor Analysis, Chauvin, Hermand and Mullet (2007) tested this structure on a new sample of French participants. They retained an 8-factor structure; that is, they did not take into account two factors (Domestic hazards and Urban violence) that they viewed as redundant with the other factors (Common and individual hazards and Weapons) in their model. Chauvin, Hermand and Mullet (2007) found strong support for the structure. Finally, Macri and Mullet (2007) tested this eight-factor model on a Greek sample. Their hypothesis was that this model should be able to account for Greek data in the same way as it was able to account for French data. Using Confirmatory Factor Analyses, these authors showed that their model nicely fit the Greek data. As a result, the eight-factor model may be considered as a potentially useful tool for studying cross-national differences in risk perception.

Macri and Mullet (2007) systematically compared the rating observed in their two samples and showed numerous differences. 
Firstly, Common individual hazards were judged as riskier by Greek participants than by French participants. On nearly every hazard corresponding to this factor, the Greek ratings were between two and three points higher than the French ratings. What had been simply called common hazards was possibly only "common" to the French. For Greek people, even a plastic food container was judged somewhat risky. The Common Individual Hazards factor was the one for which the highest overall difference was observed.

Secondly, Medical care hazards were judged as riskier by Greek participants than by French participants. The differences concerned mainly hospital resources (surgery and childbirth). By contrast, regarding drugs (psychotropic or not), the differences were minimal. Most of these drugs are, in fact, imports from other European Union countries.

Thirdly, Sexual relationships with multiple partners were judged as riskier by Greek participants than by French participants. In addition to sex items, addiction items (e.g., marijuana and ecstasy) were also judged riskier by Greek participants than French participants. Not much difference, however, as regards to hazards such as weapons or pollutants were observed but one pollutant hazard received much higher ratings by Greek participants than French participants: Cleaning of Tankers at Sea. This is possibly because the Greek population is very sensitized to sea pollution by tankers. Greece is a country with a strong maritime tradition. Many boats and tankers sail under the Greek flag. Therefore, the Greek press usually devotes much attention to maritime disasters such as sea pollution caused by tankers. Greek ratings were not always higher than French ratings. For five items, French ratings were much higher than Greek ratings. These items are Amphetamines, Asbestos, Cadmium in batteries, Chloro-Fluoro-Carbon, and Nuclear Reprocessing Plants.

Regarding the media coverage hypothesis, it can be stated that some of the differences evidenced in the Macri and Mullet's study speak in favor of this hypothesis. Until now, few people in France have directly suffered from the five hazards that have just been mentioned. These hazards have, however, been highly publicized in France (and not in Greece). Amphetamines (and other substances) are now intimately linked in French minds with the "Tour de France". A vast campaign of "asbestos removal" from all public buildings has been launched in France.
Also, several alarming results about a higher rate of leukemia in children living close to the nuclear reprocessing plant in La Hague have been published in the French press and commented about on TV. As a result, it is possible to attribute the higher French ratings to the differences in media coverage between the two countries.

The differences shown on the Medical Care factor also partly speaks in favor of the media hypothesis. The Greek TV has recently broadcasted several programs denouncing the poor state of public hospitals in Greece. Also, popular periodicals (e.g., Apoghevmatini News) reported the results of several surveys collecting data taken from 21 State hospitals in Athens and the surrounding area. The conclusion of these reports was that the public health care system has been literally abandoned by the State. For instance, the shortage in hospital staffing was as high as $35 \%$ in 2002. The differences shown on the Medical Care factor may, however, also be partly explained by the effect of direct exposure to the risk. Presently, the degradation of the public medical system is such that many Greek people may have already directly suffered from the situation (personally or through a relative): ten years ago, the public sector covered $70 \%$ of medical care whereas today only $52 \%$ is covered.

Other differences, however, cannot be attributed to the media coverage differences between the two countries. The Greek press has not knowingly attracted public attention to the risk posed by hazards like plastic food containers, hair dyes, or cleansers. On the contrary, these items are usually the object of advertising campaigns that tend to present them in a positive light. The reason why Greek ratings are higher than French ratings may be that French people are more familiarized with these items than Greek people. Newness, a dimension that was already studied in previous works on risk perception (Slovic, 1987; Mullet, Duquesnoy, Raiff, Fahrasmane, \& Namur, 1993), might be a better explanation than media coverage for the observed differences.

In the same vein, differences related to sexual relationships with multiple partners cannot be easily attributed to differences in media coverage. In France, as well as in Greece, the public has been informed about the risks of contamination through sexual encounters. One possible reason why Greek ratings were much higher than French rating could be related to the "public mores." Therefore, Morality (a dimension studied in 
previous works on risk perception, Sjöberg and Winroth, 1986; Mullet et al., 1993) might be a better explanation than media coverage for the observed differences.

In summary, Macri and Mullet's study showed that (a) the typology proposed by Bouyer et al. (2001) can be a useful tool for analyzing and understanding cross-national differences in risk perception, (b) although the media coverage hypothesis can explain some of the observed differences, (c) it is not sufficient for explaining all observed differences and thus it needs to be extended by dimensions such as morality (Sjöberg and Winroth, 1986; see also the evaluative factor in the study by Mullet et al., 1993), newness (close to the Unknown factor in Slovic, Fishhoff and Lichtenstein, 1985), and direct exposure to the risk, and (d) these hypotheses are not necessarily concurrent ones; they are best described as "complementary," especially, as discussed in Macri and Mullet, in the case of medical care.

\section{Conclusions}

Three conclusions emerge from the present analysis. First, societal risk perception considerably differ between Nordic countries and the rest of present day world. In the Nordic countries, the overall level of perceived risk was comparatively lower than it was in most countries that were considered in the present study. The only countries where the overall level of perceived risk was similar or lower to the level of perceived risk in the Nordic countries were countries forming the former Communist block. The basic reasons why participants in these two clusters gave relatively low ratings to the many hazards appear to be similar. Participants in communist countries were not well informed about accidents, and participants in Nordic countries are seemingly led to believe that these accidents only occur into other countries.

Second, the media play an important role in shaping people's societal risk perception. In fact, the clusters that were observed partly reflected the structure of the existing information agencies. Participants in the Western cluster (and to a lesser extent in the sixth cluster) have access to the same (Western) sources of information (e.g., United Press, Associated Press, France Press). Participants in the Arab cluster have access to specific Arab sources of information (e.g., KUNA), and participants in the Nordic cluster have access to media that tend to emphasize the relative security people living in Scandinavia experience by comparison with people living in other parts of the world. As regards the Developing country cluster, however, no identifiable common source of information seems to exist. What these countries have in common is a strong desire for economic growth, and few concerns for environment preservation and human security.

Third, as evidenced by more analytic approaches, other factors than media coverage must, however, also be taken into account for explaining cross-country differences in risk perception. These factors include dimensions such as familiarity/newness' degree with risks, morality, and direct exposure to the risk.

\section{Abstract}

The study was aimed at structuring the crosscountry differences in risk perception that have been reported in the literature, using cluster analysis. A 30-hazard x 19-country matrix was composed using as inputs the mean risk estimation levels available in the literature, and cluster analysis was conducted on this matrix. Six clusters of countries were found: A Communist bloc cluster (USSR and Hungary), a Nordic cluster (Finland, Norway, Sweden), an Arab cluster (Egypt and Kuwait), a Developing countries cluster (Brazil and South Korea), a Western cluster (France, Portugal, Spain, USA), and a cluster comprised of four countries or territories (Burkina Faso, China-Hong-Kong, China-Macao, Russia) which only common denominator seems to be that these countries are countries in which many economical and/or societal problems exist. The factors that may explain this clustering are discussed, and a new, more analytic approach to cross-national differences in risk perception is suggested.

Key-words: societal risk perception, cross-country differences in risk perception, cluster analysis, media coverage.

\section{References}

Ahmed, R., Macri, D., \& Mullet, E. (2006). Societal risk perception among Egyptian adolescents and adults. Journal of Northern-Africa Studies, 11, 323-334.

Ahmed, R., \& Mullet, E. (2007). Societal risk perception in Arab countries: The case of Kuwait. Unpublished Manuscript.

Boholm, A. (1998). Comparative studies of risk perception: A review of twenty years of 
research. Journal of Risk Research, 1, 135163.

Bouyer, M., Bagdassarian, S., Chaabane, S., \& Mullet, E. (2001). Personality correlates of Risk Perception. Risk Analysis, 21, 457-465.

Brun, W. (1992). Cognitive components in risk perception: Natural versus manmade risks. Journal of Behavioral Decision Making, 5, 117-132.

Cha, Y.-J. (2000). Risk perception in Korea: An application of the psychometric paradigm. International Journal of Risk Assessment and Management, 1, 42-51.

Chauvin, B., Hermand, D., \& Mullet, E. (2007). Risk perception and personality facets. Risk Analysis, 27, 171-185.

Englander, T., Farago, K., Slovic, P., \& Fischhoff, B. (1986). A comparative analysis of risk perception in Hungary and the United States. Social Behavior, 1, 55-66.

Finucane, M. L., \& Maybery, M. T. (1996). Risk perception in Australia. Psychological Reports, 79, 1331-1338.

Goszczynska, M., Tyszka, T., \& Slovic, P. (1991). Risk perception in Poland: A comparison with three other countries. Journal of Behavioral Decision Making, 4, 179-193.

Karpowicz-Lazreg, C., \& Mullet, E. (1993). Societal risks as seen by a French public. Risk Analysis, 13, 253-258.

Kasperson, R. E., Renn, O., Slovic, P., Brown, H. S., Emel, J., Goble, R., Kasperson, J. X., \& Ratick, S. (2000). The social amplification of risk: A conceptual framework. In P. Slovic (Ed.), The perception of risk (pp. 232-263). London: Earthscan.

Keown, C. F. (1989). Risk perception of Hong Kongese vs. Americans. Risk Analysis, 9, 401-405.

Koné, D., \& Mullet, E. (1994). Societal risk perception and media coverage. Risk Analysis, 14, 21-24.

Macri, D., \& Mullet, E. (2007). Cross-national validation of an eight-factor model of societal risk perception, Journal of Human and Ecological Risk Assessment, in press.

Mechitov, A., \& Rebrik, S. (1990). Studies of risk and safety perception in the USSR. In K. Borcheding, O. I. Larichev, \& D. M. Messick (Eds.), Contemporary issues in decision making. Amsterdam: Elsevier.

Mullet, E., Duquesnoy, C., Raiff, P., Fahrasmane, R., \& Namur, E. (1993). The evaluative factor of risk perception. Journal of Applied Social Psychology, 23, 1594-1605.

Mullet, E., Lazreg, C., Candela, C., \& Neto, F. (2005). The Scandinavian way of perceiving societal risks. Journal of Risk Research, 8, 19-30.

Muñoz Sastre, M. T., Gatelier, S., Portell, M., Neto, F., \& Mullet, E. (2006). Societal risk perception among a sample of Spanish students. Contemporary Politics and Economics of Europe, 18, 127-138.

Neto, F., \& Mullet, E. (2000). Societal risk perception by the Portuguese public. European Review of Applied Psychology, 49, 155-163.

Neto, F., \& Mullet, E. (2001). Societal risks as seen by Chinese students living in Macao. Journal of Risk Research, 4, 63-73.

Nyland, L. G. (1993). Risk perception in Brazil and Sweden. Stockholm: Center for Risk Research.

Rodionova, N., Vinsonneau, G., Rivière, S., \& Mullet, E. (2007). Societal risk perception in present day Russia. Journal of Human and Ecological Risk Assessment, in press.

Rohrmann, B. (1994). Risk perception of different societal groups: Australian findings and cross national comparisons. Australian Journal of Psychology, 46, 150-163.

Savadori, L., Rumiati, R., \& Bonini, N. (1998). Expertise and regional differences in risk perception: The case of Italy. Swiss Journal of Psychology, 57, 101-113.

Savadori, L., Rumiati, R., Bonini, N., \& Pedon, A. (1998). Risk perception: Experts vs nonexperts. Archivio di Psicologia, Neurologia e Psichiatria, 59, 387-405.

Sjöberg, L. (2000). The methodology of risk perception research. Quality \& Quantity, 34, 407-418.

Sjöberg, L., \& Winroth, E. (1986). Risk, moral value of actions, and mood. Scandinavian Journal of Psychology, 27, 191-208.

Sjöberg, L., Kolarova, D., Rucai, A. A., Bernström, M. L., \& Flygelholm, H. (1996). Risk perception and media reports in Bulgaria and Romania. Stockholm: Center for Risk Research.

Slovic, P. (1987). Perception of risk. Science, 236, 280-285.

Slovic, P., Fischhoff, B., \& Lichtenstein, S. (1985). Characterizing perceived risk. In R. Kates, C. Hohenemser, \& J. X. Kasperson (Eds.), Perilous progress: Managing the hazards of technology (pp. 91-125). Boulder CO: Westview Press.

Teigen, K., Brun, W., \& Slovic, P. (1988). Societal risk as seen by a Norwegian public. Journal of Behavioral Decision Making, 1, 111-130. 